\title{
"It's not a simple thing, co-publishing": Challenges of co-authorship between supervisors and students in South African higher educational contexts
}

\section{Clowes}

University of the Western Cape

lclowes@uwc.ac.za

\author{
T. Shefer \\ University of the Western Cape \\ tshefer@uwc.ac.za
}

\begin{abstract}
Knowledge production in South Africa remains framed by the legacies of apartheid. Developing emerging authors and local knowledges through co-authorship between supervisors and post graduate students is an important strategy aimed at challenging these legacies. This paper draws on in-depth interviews with students and supervisors to explore their experiences of co-authorship. Findings indicate that while insisting that co-authoring has value, several students also note their discomfort with elements of the process. While insisting students' work be disseminated, and expressing willingness to engage in the mentoring that this requires, supervisors also articulate discomfort with processes offering opportunities for personal career development. Given increasing emphasis on co-authorship we suggest the power inequalities expressed through the supervisor/student relationship be made more transparent. Knowledge production through co-authorship is best served by collaborations between authors who are more equally empowered and who are more critically aware of the challenges such collaborations are likely to present.
\end{abstract}

Keywords: Co-authorship, Mentoring, Supervision, Knowledge production, Postgraduate research

\section{Introduction}

Authorship, as Robert Berk observed over two decades ago, is "the bargaining chip used for promotion, salary increases, grant funding, research time, laboratory space, and other rewards of academia" (Berk 1989, 719). In South Africa authorship and publication records are key criteria for promotion in tertiary education institutions, for academic rating and for access to research funding. The social, political and ideological context of apartheid has seen local scholarship and knowledge production dominated by raced and gendered group interests, with research processes "fraught with the reproduction of gendered and racialised power inequalities and exploitation" (Shefer and Ratele 2006, 234; Christiansen and Slammert, 2005). In the second decade of the twenty firstcentury most publishing academics are not only white and male but also over the age of 50 years (Council on Higher Education 2009; Christiansen and Slammert, 2005; Bennett 2000, Duncan, Van Niekerk and Townsend 2004, Fester 2000, Mama 2000, Maurtin-Cairncross 2003; Holtman, Mukwada and Du Plooy, 2009). 
Attempts to develop authorship and transform the inequalities underpinning local knowledge production cross structures of higher education. South Africa's The National Research Foundation (NRF) has promoted the production of young doctoral candidates and offered financial awards for mentoring emerging researchers and authors through the Thuthuka and Mellon Early Research Career Development programmes. Authorship development forums at several universities have established mentorship processes aiming at promoting co- authorship and co-editorship between established and emerging writers (see Duncan, Seedat, Van Niekerk, de la Rey, Gobodo-Madikizela, Simbayi and Bhana 1997; van Niekerk, Diedericks, de la Rey, Shefer and Duncan 1998; van Niekerk and Shefer 2001; Shefer, Shabalala and Townsend 2004). An increasingly common strategy has been team and co-authorship between supervisors and students/postdoctoral candidates the latter often colleagues). As articulated in the NRF Mission Statement the broad aim of national policy is that local researchers "contribute to the knowledge economy in South Africa by attaining at least 1\% of global research and development output by 2015". At one local university, the Revised Research Policy (University of the Western Cape, 2008) insists that academic staff members be encouraged to "publish research findings jointly with the student".

There is, globally and locally, an increasing expectation that students, especially at the doctoral level, should be productive as authors during their studies (Lee and Aitchison, 2009) and the pressure to publish increases once their studies are completed (Aitchison, Kamler and Lee, 2010; Lee and Kamler, 2008; McGrail, Rickard and Jones 2006). These pressures have been foregrounded in recent scholarship that elaborates on the development of innovative policy and practice supportive of both students and emerging researchers (Kamler and Thomson 2006; Lee and Kamler 2008). Such studies highlight challenges of writing for publication, acknowledge anxieties articulated by new authors and point to the dearth of formal induction for emerging authors (Kamler 2010; Lee 2010; Pare' 2010). Authorship development interventions such as team research and writing workshops (Aitchison, Kamler and Lee 2010), and experienced assistance (through mentorship and/or co-authorship) is increasingly underlined as valuable for developing and supporting emerging authors (Kubota 2003; Kamler 2010; Murray 2010). Kamler (2010, 80) points to the centrality of "expert guides" I through "publication brokering that supports early career writers in publishing their research" by making "explicit the complex social, cultural and political dimensions of revise and resubmit that require mediation".

While co-authorship between supervisor and supervisee arguably represents possibilities for such mentorship and induction into writing for publication it is not without its challenges. Co-authorship between individuals who are clearly in unequal positions in relation to academic resources and institutional power raises a range of ethical and political issues. A discussion on such co-authorship at a research

\section{https://repository.uwc.ac.za/}


colloquium at a local university elicited saw faculty declare that "publishing with students is tantamount to intellectual rape!" and "I'd never dream of publishing with a student".

The understanding that co-authorship between supervisors and students is inherently unethical and exploitative has lead, in the Natural Sciences, where co-authorship has a long history, to extended debates around ethics (Macintyre 1997). Collaborative research, publishing and co-authorship has been much less common in the Arts and Humanities, although this is changing. It is in the light of these ethical challenges, against a context of the need to transform local knowledge production that this study explores co-authoring experiences of a small group of supervisors and students at three universities in the Western Cape.

\section{Methodology}

The study employs a feminist qualitative methodology that foregrounds gathering rich, complex qualitative data that is sensitive to issues of gender and intersecting power inequalities at all stages of the research process (Fonow and Cook 2005; Naples 2003; Hesse-Biber 2007; Presser 2005; Ramazanoglu and Holland 2002). As outlined in table 1 below, ten in-depth semi-structured individual interviews were conducted, each lasting between one and two hours. The seven women and three men represented a range of racial and gender differences with four Black ${ }^{1}$ participants (three coloured, one African) and six white participants. These ten participants signed a consent form after being fully informed of the rationale and goals of the project and were assured of confidentiality, anonymity and the right to leave the research at any point. All names have been changed. Interviews were conducted in English, audiorecorded and transcribed verbatim whereupon a qualitative thematic analysis, broadly located in a discourse analytic tradition but with a directed focus on subjective narratives, was carried out. Participants revealed varied experiences of co-authorship. One refused to publish with her supervisor; others published with their supervisors as students and currently publish with their own students. 
Table 1: Demographic details

\begin{tabular}{|c|c|c|}
\hline Natasha & $\begin{array}{l}\text { Coloured woman in her } \\
\text { 30s; published with her } \\
\text { supervisor }\end{array}$ & $\begin{array}{l}\text { Researcher; publishes } \\
\text { alone }\end{array}$ \\
\hline Dean & White man in his $50 \mathrm{~s}$ & $\begin{array}{l}\text { Senior academic; coauthors } \\
\text { regularly with students }\end{array}$ \\
\hline Cecily-Ann & $\begin{array}{l}\text { Coloured woman in her } \\
\text { 40s; published with her } \\
\text { supervisor }\end{array}$ & $\begin{array}{l}\text { Academic, regularly } \\
\text { publishes with students }\end{array}$ \\
\hline Nthabiseng & $\begin{array}{l}\text { Black woman in her } \\
\text { 40s; published with her } \\
\text { supervisor }\end{array}$ & $\begin{array}{l}\text { Academic and student } \\
\text { finishing a doctoral degree }\end{array}$ \\
\hline Linda & $\begin{array}{l}\text { White woman in her } 50 \mathrm{O} \text {; } \\
\text { refused to publish with he } \\
\text { supervisor }\end{array}$ & $\begin{array}{l}\text { Employed in a non- } \\
\text { racademic role on campus. } \\
\text { Has not continued } \\
\text { publishing }\end{array}$ \\
\hline Joy & $\begin{array}{l}\text { White woman in her } \\
\text { 4os; published with her } \\
\text { supervisor }\end{array}$ & $\begin{array}{l}\text { Senior academic; regularly } \\
\text { publishes with students }\end{array}$ \\
\hline Catherine & $\begin{array}{l}\text { White woman in her } 5 \text { os; } \\
\text { did not publish with her } \\
\text { supervisor }\end{array}$ & $\begin{array}{l}\text { Academic; publishes with } \\
\text { her students }\end{array}$ \\
\hline John & $\begin{array}{l}\text { White man in his } 405 \\
\text { published } \\
\text { supervisor }\end{array}$ & $\begin{array}{l}\text { Researcher; } \\
\text { alone }\end{array}$ \\
\hline Sharon & $\begin{array}{l}\text { Coloured woman in hel } \\
\text { 40s; co-authored with } \\
\text { peers }\end{array}$ & $\begin{array}{l}\text { rAcademic and student } \\
\text { finishing a doctoral degree }\end{array}$ \\
\hline Leon & $\begin{array}{l}\text { White male in his } 50 \mathrm{O} \\
\text { published } \\
\text { supervisor }\end{array}$ & $\begin{array}{l}\text {;Academic and student } \\
\text { finishing a doctoral degree }\end{array}$ \\
\hline
\end{tabular}


We present the findings in two broad sections, beginning with the experiences of students before moving on to those of supervisors, whilst recognising that several supervisors had co-authored with their own supervisors when they themselves were students. Within this analytical framework we begin by exploring the positive aspects of co-authorship as reported and understood by students before elaborating on more ambivalent and/or negative experiences of discomfort. In the second section we present supervisors understandings of processes, relationships and experiences of co-authorship. We unpack ways in which both students and supervisors draw on contemporary salient identities and the power dynamics operating in and through these identities to both explain their experiences and defend their choices.

\section{Student narratives}

Most students valued their experience of co-authorship. For Nthabiseng "co-authorship with a senior person, even if it's not a supervisor ... it's an empowering initiative." Students noted how challenging they found translating their research into a publishable paper and how co-authorship with a more experienced researcher facilitated their development of writing skills and built confidence. Kamler (2008) has noted that first time authors may be devastated by critical reviews. Catherine reported that co-authoring had helped her understand that "critical feedback [from the journal] isn't a personal attack on your own personal intellectual abilities". Other participants drew attention to the significance of modelling of engagement with reviewers critiques and the demystification of the publishing process. Cecily-Ann said "It was very valuable to me ...not so much about the content but more about the process and how one responds to feedback... to see how he looked at feedback, because feedback could be incredibly demoralising.it helped me to understand how to deal with feedback." John agreed: "We got a rejection the first time we sent it. [I was] a bit devastated." His supervisor, on the other hand, was unperturbed saying "no it does happen and we must just try somewhere else, look at other possibilities." John explains that these insights were important "to see somebody in action the way I did when ...we were redoing and the chopping and changing was very very exciting ... she speaks to the academic world which I couldn't do... at that stage."

Another participant shared regret that she had not co-authored with her supervisor. Even though she has a relatively privileged background and did not lack confidence in writing, Catherine believes she would have benefited from the mentorship possibilities offered by co-authorship: "I could've published out of my honours paper and out of my masters and I didn't and I never will and that's primarily because I just didn't have a clue as to how to go about it. I had no confidence and no clue. I would've liked guidance on that."

Other students had different experiences and experienced co-authorship in more ambiguous and perhaps less empowering ways. While Joy observed that "I didn't feel 
coerced" she also reported an "unconscious obligation" to include her supervisor in publications emerging out of her post graduate research. Employment outside the university meant Linda felt able to challenge a suggestion by her supervisor, a man 10 years her senior and Head of Department, to take authorship on a paper emerging out of her thesis to which he had not directly contributed. After she had sent him the completed paper

[h]e phoned me and he said "would you mind if I put my name with your name?" And I was a bit taken aback, so I said ok ... [but] I felt unhappy about it. So within half an hour I called him back and I said "You know I'm really sorry, but I don't think it's right ... I don't think that's ok". And he tried to explain to me that it's protocol, or it's part of the regular practice for supervisors to put their names with the students that they had supervised from work that came out of a thesis....and I just didn't feel ok about it. So I just stuck to my guns and said "I'm not prepared to do that".

Linda's ability to insist on sole authorship represents a sense of agency and power probably linked to her class and race location and experience as a professional employed outside the university. Others had fewer resources and claims to authority upon which to call. John's ability to challenge something he now understands as unethical was linked to his youth and lack of familiarity with academic processes "I wrote this paper.. .and when I'd written it he told me he wanted his name on it which at that stage I was kind of bullied into, because I didn't think there was any option, but afterwards .I thought no, why did I allow that to happen, you know I certainly wouldn't allow it now. Now, after a bit of experience in life I would have told him to take a hike."

Seniority, age, race and gender intersected to shape the experiences of a female student who hoped to publish out of her Masters degree. Employed as a junior academic in the department and supervised by a senior white man, Nthabiseng reported that "he came up with the idea [of co-authoring], but after I had written the thesis I also thought 'I need to get an article from this' because I could see there was something interesting that I found out." Despite her willingness to write independently "he ... suggested that we do it together. And uh I couldn't refuse and say no I've already thought about it, because I thought maybe, by working with him .it may be an advantage for me." In addition, limited familiarity with the political and structural contexts in which authorship is located meant that Nthabiseng did not realise the significance of name order. "Unfortunately we never discussed that, I was not aware of the importance of the sequence of names." It was only later that she began to understand that far from increasing the status of her work, having her supervisor's name come first actually meant she lost authorship/ownership of her own research: "I realised recently when somebody mentioned that he saw my article $\ldots$ and he was surprised that I'm not right at the beginning. I'd thought if his name comes first this article will have status."

\section{https://repository.uwc.ac.za/}


Other students confirmed that they too were overawed by their supervisors. Joy noted that students "idolise" their supervisor, while Leon remembered putting "her on this pedestal, she was this academic out there and she's so much superior to me." As Natasha explained, such deference may be compromising. Her supervisor had been "very clear about [name order] from the start. Had she not said that 'you need to be first author', I'm not sure if I would've said 'listen I need to be first author here', because she was the person I relied on for assistance and support with my writing of my PhD." Linda reports that when she had resisted his request to add his name to her article, her supervisor had another student who was also writing an article. "I phoned her up before I phoned him... and I said 'what are you going to do?' She said 'no I'm just going to let him put his name there because it's not worth it to me, I have to have a relationship with him afterwards'. She was working in the [department]." Employment as a more junior person in the same department as her supervisor undermined this student's capacity to resist his request.

While it is relational inequalities built primarily around seniority, age, gender, race and class that are foregrounded in and through these narratives, there are other subject locations that could have been added. As Natasha observed, individuals are always located within a nexus of relational power inequalities:

There is always power in every relationship ... all relationships are unequal ... so for every relationship we have in our lives we actually need ... to talk about this, whether it's friendship, a lover, a husband, whether it's a child. Co-authoring shouldn't be any different, but we don't even have those conversations in our personal lives - it comes out in arguments, it comes out in fights, it comes out when something happens ... There is a problem around co-authorship... because of our divisions around race ... it should be that the ... supervisor should be obligated to bring up having that conversation about power. But I don't know how you can force senior people to have a discussion about power.

While there are clearly exceptions, supervisors, as we discuss below, are often aware of and challenge these power inequalities. On the one hand supervisors emphasise that it is important that students work be published precisely because of the need to challenge Northern hegemonies around authentic knowledge. At the same time, there is a level of discomfort around the ways in which this frequently serves supervisor's interests more than it does students.

\section{Supervisors' narratives}

Central to co-authorship is an understanding by supervisors that students' work, especially pre-doctoral research, is unlikely to be published but that much of this work should be converted into more accessible formats. Joy insisted that "If you're studying, if you're creating knowledge, if you're doing research, you must publish ... 
the whole point [of research] is to make that knowledge that you've produced accessible and available."

Supervisors raised a range of benefits that they believed were inherent in copublishing, both for their students and themselves. Cecily Ann drew attention to students' lack of confidence "they often believe that they don't have the capacity ... so they exclude themselves from the process automatically by the way they think about who publishes and who doesn't publish." Supervisors suggested that co-authorship was important precisely because of the confidence building it facilitated. "We've got enough evidence" claimed Joy " to show that students who publish with, if it's a positive experience, their supervisors, go on to publish on their own and to become confident in their positions as researchers, authors, writers, publishers." For Joy co-authorship was "clearly a strategy we want to encourage."

Further underlining the significance of encouraging students to publish Cecily Ann suggested "it's important to think about how we convey the importance of publishing, how we convey the message about why [students] should think about publishing, that it isn't such a fancy thing that people do, that their voices are important." Joy observed that co-authorship served as an induction to academic knowledge production and that publishing should become normative "just like you need to produce a doctorate, you should publish a paper, and it should be strongly advised you work with your supervisor for the mentorship." Joy further insisted that "the doctorate is supposed to prepare you ... as somebody who researches and writes" and that "if you cannot publish during or after a doctorate it's highly problematic, you're not an academic then and you shouldn't have done your doctorate because then what was the point? Just to get the doctor title?

While the dissemination of research through publication is important in terms of knowledge production, publishing is also central to the development of academic careers. Several supervisors drew attention to the tensions between the need to disseminate knowledge through publishing, and the ways in which existing axes of power and privilege shape co-authorship in ways that usually privilege supervisors. Co-authorship, Joy noted, is "open to abuse without even the student realising it." Dean observed that "people in my department say 'I haven't been able to publish anything this year because I haven't had any students'. So where people's entire careers are dependent on co-publishing with students I think it's bad." Likewise, while insisting on the importance of disseminating students work, another supervisor also articulated her disquiet with a process in which she would benefit: "You see there's a discomfort that I'm doing it for my own benefit ... although there are very important issues ... I mean it's very important that [it] be published". In acknowledging these tensions, Cecily Ann reported that "I pacify my concerns about whether I'm doing it for myself... I tell them that they will be first author."

Cecily-Ann also expressed discomfort over normative practices in her department where colleagues routinely took first authorships of students' research. "If they 
[colleagues] write the articles then they are first authors, but at some level I found that quite unfair towards the students who had actually done all the work". At the same time she noted that students "wouldn't write the article... they're not invested in getting it out as much as I am." Recognising that students themselves were unlikely to rework their research for publication also meant that if such work was to be reworked for publication the burden would fall primarily on supervisors. Cecily Ann had decided that "if I write an article with a student then their names will always be first irrespective of whether I'm writing the whole article or whether they're writing." Dean reported that he employed a similar approach: "I always put the student first... who's going to know? The students who have done relatively little, but some of them I've put in a huge amount". In challenging positionalities that confer privilege and in insisting students take first authorship of their own research even when they have not made substantial contributions to the published paper, Dean also foregrounded the longer term benefits he believed accrued to students "with a number of them it's launched writing careers."

Several supervisors drew attention to historical legacies of inequality that continue to privilege some and marginalise others in terms of writing for publication. Dean pointed to "a sort of meta language... which opens the hidden side of the academy to students ... in a way that even doing a doctorate doesn't... It's about identity. It is a sort of rite of passage, but it's very hidden." As Cecily Ann also observed, converting a research study into a publishable paper demands very specific writing skills and that many of her students "struggle with [the] very tight style of writing that's needed." Dean also alluded to "hidden techniques of writing" that are hard to teach. "You can't say 'cut out four paragraphs' you've got to show, you've got to cut out the four paragraphs".

In commenting on the "tricks of... putting things in fewer words, the cunning way of linking what you have to existing debates so that it's much more difficult to get your paper rejected," Dean also drew attention to the challenges of developing these skills in emerging authors. "I get students" he said "who try and write in a highfalutin way ... they don't make sense, they don't feel confident in the language they use, it's unclear, and it's irritating ... and then you have to say 'no I don't need 15 syllables, I want one syllable' and 'no, no, no I don't want 6 sentences, I want 3 words." Modelling and transmitting these skills can be fraught with difficulties linked to the contemporary social landscape in which certain subjectivities are more valued than others: "Some people" noted Dean "experience it as very patronising, [as if] I was saying 'you're so stupid you must write like this'." In contrast "I write ... much more easily than my students do, so they're struggling to say something and I go click click click and it's done." But while supervisors do acknowledge their own expertise they don't always consciously recognise or acknowledge the 'cultural capital' that underpins their expertise. As Dean notes "I'm just staggered about how much people just don't know - and I don't know how I know, because nobody taught me. [You] work it out as you go along." 
Located in positions of privilege structured around age, gender, race and class, combined with decades of institutional knowledge, legitimised by academic titles and publishing records, further legitimised by liberal notions of self-help and individual hard work, it is often very difficult to see the ways in which individual achievements are rooted in society wide patterns of power and privilege. It is arguably much easier to understand how one is oppressed than how one is privileged. And, if it is difficult for the individual to appreciate, even when there is intellectual awareness of how one has benefited from the legacy of apartheid, it is often even more difficult for supervisors to initiate conversations about the social inequalities that have shaped and continue to shape processes, experiences and understandings of their own practices of co-authorship in relation to their students. Several participants suggested that despite the difficulties we need these conversations. Natasha recommended "a long conversation when you start writing ... a conversation about where you are coming from, about power... It's a difficult conversation to have and it's a very uncomfortable conversation to have, but I think it needs to be done." For Natasha such a conversation is "not only about the obvious constructs of race and gender, it's about where we come from, where we live, how we think about the world." Catherine articulated similar sentiments: "What we need to do is acknowledge that there are benefits for both but that it shouldn't be benefiting just one at the expense of the other and that the process needs to be quite transparent."

While it seems clear such conversations are necessary, care needs to be taken to avoid monolithic understandings positioning co-authoring supervisors as inevitable oppressors or students as lacking agency. On the one hand supervisors understand themselves to make significant and empowering investments in their students through, for example, facilitating access to research funds. Cecily Ann records that she recruits students early "so that they can apply for NRF... and then I get them to ... collect data quickly so that they have enough for a conference paper." This is part of a deliberate strategy to structure the research process in ways that develop skills and expertise: "then I have used those ... conferences for my students to present at, and if they are NRF, they can apply for additional conference funding. So they've had many kickbacks from being involved." Other supervisors revealed how students sometimes took for granted the huge amount of time and energy supervisors invested in skills development. "I put blood and sweat into their thesis that I feel like I almost wrote that thing" notes Joy, " and then they go off and do presentations, there's no acknowledgement... of the massive contribution I've made." Students could also fail to acknowledge what supervisors saw as commitment above and beyond the call of duty, as Joy explained, "one can also build up resentment that you've been taken advantage of." Several of the supervisors involved in this study described feeling 'owed' or 'exploited'. According to Cecily Ann "the level of work I put in with the student justifies me to expect that I will be at least the second author ... I put a lot of work in ... they owe me payback." Dean had a similar analysis when speaking of an ex-student with whom he co-authored a paper "this person's actually enraged with me 
and has said 'you never built capacity in your life' and ... that person without my help I completely rewrote what they'd written - would not be in the senior academic position that they are in today."

In sum, there is some awareness of historical legacies of inequality that may be enacted in relationships with students in the narratives of supervisors who co-author with students. It seems clear too that while these structures of inequality position supervisors as more powerful, assumptions that supervisors are inevitably the abusers are overly simplistic. It is important to recognise that students do indeed have power and are sometimes able to use it to challenge what they see as unethical practices, and sometimes in ways that inadvertently undermine and marginalise the supervisors. At the same time, in acknowledging the complex and intersecting legacies of inequality that permeate supervisor/ student relationships, and in their commitment to challenging these inequalities, some supervisors perhaps overcompensate. Where supervisors allow for their own exploitation as a part of the mentoring of emerging researchers, or as part of a challenge to global hierarchies around knowledge production, they verge on disempowering themselves, inadvertently re-inscribing the paternalistic hierarchies they aim to challenge.

\section{Conclusion}

Over a decade ago Gail Smith $(2000,57)$ recorded that her "greatest barrier to writing publically was fear - fear of being criticised, fear of being ridiculed, fear of expressing an opinion, and the subconscious belief that I did not have the right to an opinion." At about the same time Jeanne Prinsloo (2000, 55) suggested that Smith was not alone with her fears, that many emergent writers "do not easily imagine themselves among the powerful. Many do not readily believe that they have insights of such significance that they might count as knowledge or make an interesting and useful contribution to the existing body of knowledge." While co-authorship has been an important strategy foregrounded in national and institutional policies aimed at challenging these anxieties and understandings it also poses ethical challenges because publication remains the cornerstone of academic career development. It is against this backdrop that this study explored understandings of co-authorship between supervisors and their students at 3 universities in the Western Cape. While we make no claims to generalise from the findings of a qualitative study, the range of experiences is likely to resonate with many of those who have participated in similar co- writing ventures. Our participants agreed that students' work should be more widely disseminated, that a conscious awareness of the complexities embedded in collaborations between differently positioned subjects is important, and that publication be foregrounded more clearly as a 'natural' outcome of research. Both students and supervisors involved in this study agree that post graduate research can - and should - do more than simply earn a degree. There is also agreement that the dissemination of knowledge through co-authorship can be experienced as a positive and supportive process for transforming post graduate students into emerging authors and for promoting the development of academic careers (Aitchison, Kamler and Lee, 2010). 
At the same time the complexity of the supervisor/student relationship and the potential for abuse that was recognised by participants needs to be constantly interrogated. While several students insist that the process of co-authorship had value they also record sometimes acute discomfort. Similarly, while insisting that students' work should be disseminated and expressing their willingness to engage in the mentoring that this requires, supervisors also express discomfort in processes that simultaneously offer opportunities for exploitation of both the self and the student. Such contradictory experiences foreground the importance of ensuring the duties and obligations of both supervisor and student are clear in terms of converting a research paper into a publishable paper. As Natasha observed co-publishing "is not a simple thing". If, in South Africa, we are to transform processes of knowledge production and demographics of authorship that have long been dominated by minority male and white researchers we need to confront this complexity directly: the pressures on South African academics and their post graduate students to publish are unlikely to diminish in the near future. 


\section{References}

Aitchison, C., A. Shumba and A. Lee. 2010. Introduction: Why publishing pedagogies? In Publishing pedagogies for the doctorate and beyond, eds. C.Aitchison, B. Kamler and A. Lee. Oxon: Routledge.

Berk, R.N. 1989. Editorial: Irresponsible Co-authorship. American Journal of Roentgenology, 152: 719-720.

Bennett, J. 2000. The politics of writing.Agenda, 46: 3-12.

British Sociological Association 2001.Authorship guidelines for academic papers [Online]. Available at http://www.britsoc.co.uk/Library/authorship 01.pdf (accessed 26 July 2010).

Christiansen, I.M. and L.Slammert. 2005. A multi- faceted approach to Research development (I): Addressing the Myths. South African Journal of Higher Education 19 (6): 1047-1061.

Council on Higher Education (CHE) 2009. Higher Education monitor: The state of Higher Education in South Africa: A report of the CHE Advice and Monitoring Directorate. [Online]. Available at:http://www.che.ac.za/documents/dooo201/ Higher_Education_Monitor_8.pdf (accessed 9 November 2011).

Duncan, N., A. van Niekerk and L. Townsend. 2004. Following apartheid: authorship trends in the South African Journal of Psychology after 1994. South African Journal of Psychology, 34(4): 553-575.

Duncan, N., M. Seedat, A. van Niekerk, C. de la Rey, P.Gobodo-Madikizela, L.C. Simbayi and A. Bhana. 1997. Black scholarship: Doing something active and positive about academic racism. South African Journal of Psychology, 27(4): 201-205.

Fester, G. 2000. Women writing for their rights. Agenda, 46, 42-47.

Fonow, M. M. and J. A. Cook. 2005. Feminist Methodology: New Applications in the Academy and Public Policy. Signs, 30 (4): 2211-2236.

Hesse-Biber, S. 2007.The practice of Feminist In-Depth Interviewing. In Feminist Research Practice, eds. S. Hesse-Biber and P.L.Leavy.Thousand Oaks: Sage

Holtman, L.,G. Mukwada and L. Du Plooy. 2009. Education and the challenges for change status quo report (July 2009) 2003-2006.Pretoria: National Research Foundation. [Online]. Available at: http://www.nrf.ac.za/files/Document\%20 
1-Status\%20Quo\%20of\%20Education\%20Focus\%20Area.pdf (Accessed 20 April 2012).

Kubota, R. 2003. Striving for original voice in publication?: A critical reflection. In Writing for scholarly publication: Behind the scenes in language education, eds.V.P. Casanave and Vandrick. Mahwah, NJ: Lawrence Erlbaum Associates.

Kamler, B. 2010. Revise and resubmit: the role of publication brokers. In Publishing pedagogies for the doctorate and beyond, eds. C. Aitchison, B. Kamler and A. Lee. Oxon: Routledge.

Kamler, B. 2008. Rethinking Doctoral Publication Practises: Writing from and beyond the Thesis, Studies in Higher Education, 33 (3), 283-94.

Kamler, B. and P. Thomson. 2006. Helping doctoral students write: Pedagogies for supervision. Oxon: Routledge.

Lee, A. and B. Kamler. 2008. Bringing pedagogy to doctoral publishing. Teaching in Higher Education, 13(5): 511-523.

Lee, A. 2010. When the article is dissertation: pedagogies for a $\mathrm{PhD}$ by publication. In Publishing pedagogies for the doctorate and beyond, eds. C. Aitchison, B. Kamler and A. Lee. Oxon: Routledge.

Lee. A and C. Aitchison. 2009. Writing for the doctorate and beyond.In Changing practises of Doctoral education, eds. D. Boud and A. Lee. London: Routledge.

Macintyre, S. 1997. Conventions, ethics and laws in journal publishing. Social Science and Medicine, 45(1): 1-2.

McGrail, M., C. Rickard and R. Jones. 2006. Publish or perish: A systematic review of interventions to increase academic publication rates. Higher Education Research and Development, 25(1): 19-35.

Mama, A. 2000. Why we must write: personal reflections on linking the alchemy of science with the relevance of activism. Agenda, 46: 13-20.

Maurtin-Cairncross, A. 2003.Creating space for publication: challenges faced by women academic staff members at historically Black South African universities.D Phil dissertation. Cape Town: University of the Western Cape.

Murray, R. 2010. Becoming rhetorical.In Publishing pedagogies for the doctorate and beyond, eds. C. Aitchison, B. Kamler and A. Lee. Oxon: Routledge. 
Naples, N. 2003. Feminism and Method: ethnography, discourse analysis and activist research. London: Taylor and Francis Books.

National Research Foundation: Overview. [Online]. Available at:http://www.nrf. ac.za/about_overview.php (accessed 5 August 2009).

Pare', A. 2010. Slow the presses: concerns about premature publication. In Publishing pedagogies for the doctorate and beyond, eds. C. Aitchison, B. Kamler and A. Lee. Oxon: Routledge.

Presser, L. 2005. Negotiating power and narrative in research: Implications for feminist methodology. Signs, 30 (4): 2067-2090.

Prinsloo, J. 2000. Teaching talk back: reflections on a workshop for women writing for publication. Agenda, 46: 55-58.

Ramazanoglu, C. and J. Holland. 2002. .Feminist methodology: challenges and choices.London: Sage.

Shefer, T. and K. Ratele. 2006. New questions, old answers? Gender and "race" in post-apartheid South Africa. In A race against time: Psychology and challenges to deracialisation in South Africa, eds.G. Stevens, V. Franchi and T. Swart. Pretoria: Unisa Press.

Shefer, T., N. Shabalala and L. Townsend. 2004. Women and authorship in postapartheid psychology. South African Journal of Psychology, 34(4): 576-594.

Smith, G. 2000. From suffering in silence, to drawing strength from the margins. Agenda, 46: 34-41.

University of the Western Cape, Revision of the Research Policy 2008.[online]. Available at: $\quad$ www.uwc.ac.za/? module $=\mathrm{cmsandaction}=$ showfulltextandid $=\mathrm{ge}$ n11Srv7Nme54_1135_(accessed 5 August 2009).

Van Niekerk, A., M. Diedericks, C. de la Rey, T. Shefer and N. Duncan. 1998. Shifting the publications game: The case of a textbook project at a historically black university. Perspectives in Education, 17(2): 71-86.

Van Niekerk, A. and T. Shefer. 2001. Authorship and publication: Challenging academic racism. In Race, racism, knowledge production and psychology in South Africa, eds. N. Duncan, A. Van Niekerk, C. de la Rey and M. Seedat. New York: Nova Science Publishers. 